\title{
Discursos IV e V do tratado De historia, para entenderla y escribirla (1611)*
}

\author{
Luis Cabrera de Córdoba
}

Escrevo a importância da história, a do bom historiador, as partes que devem ter, as de legítima e perfeita história e como se fará tal.

\section{Discurso IV - Das partes e definição da história}

A história tem etimologia, definição, divisão, subdivisão e segunda subdivisão, objeto, fim, alma, matéria, figura ou corpo. Platão, que disse todas as coisas com entendimento, conselho, verdade e sutileza em nome de Sócrates, em Cratila, perto do fim, tenta provar que a palavra história declara a natureza de sua obra: porque segundo sua interpretação, história é o mesmo que histesiton rum, que quer dizer em latim, sistit fluxum, detenção do fluxo corrente dos acontecimentos, porque sem a história passariam voando para o esquecimento.

Pesevino diz contra Platão ser chamada história porque nos propõe à vista

202 e à especulação das coisas. Santo Isidoro diz que vem do grego historin, que significa ver, porque antigamente chamavam por história a que foi feita por quem viu as coisas e escreveu. Assim definiu Verrio Flaco com Aulo Gélio, Plinio, Teofrasto e Luciano, dizendo: a história é narração das coisas feitas por meio de quem tenha visto; mas Estrabão, a quem seguem alguns antigos, como Políbio, Josefo e muitos modernos, pensa que a história narra as coisas que viu e ouviu os que estiveram presente, porque o vocábulo grego quer dizer também ver, conhecer e ouvir perguntando.

Mas em tudo isso há erros, porque não pode ser o mais principal ver tudo o que se faz e pôr em uma longa e variada narração. Seria pequena a história daquele que somente viu, porque de modo forçoso seria preciso acreditar no que ele disse; não um, senão muitos, que não encontrarão a perfeita narração que ele pressupôs ser uniforme. Por ser ordinário e certo variar, haverá de argumentar sobre a possibilidade na diversidade dos fatos que se refere, para verificar a fineza da verdade e estabelecer o que mais verdadeiro ou verossímil se parece. Vale mais estas coisas na relação do que a presença. Se todos podem escrever somente o que viram, condenem com este título a gregos e latinos que prosseguiram com os sucessos de outra nação, e aos que contaram histórias de séculos mais atrás que suas vidas, e aos que não peregrinaram toda a terra pessoalmente, senão por meio de seus livros. Cícero diz ser a história coisa verdadeiramente feita,

* Tradução realizada por Maria Emília Granduque José. 
mas da idade nossa, afastada e remota. Já Ivan Costa diz ser a história narração verdadeira, clara e com ordem, distinta de algumas coisas passadas ou presentes, para imprimir sua memória na memória dos homens.

Eu digo que a história é a narração de verdades por homem sábio, para ensinar a bem viver. Consta esta definição de gênero e de diferença, e contêm as quatro causas: material, formal, eficiente e final. O gênero é narração, de que se tratará quando se toma pelo corpo ou figura da história. A diferença é verdades, com que exclui a narração da poesia, que é de mentiras: e assim há muita diferença e desacordo entre a história e a poesia, não por ser esta em verso e a outra em prosa escrita, como vulgarmente se pensa, o verso não é próprio da faculdade poética, a imitação sim faz a poesia, porque há nela em prosa.

Verifica Suidas com as comédias de Sofrón e Senarco, nos diálogos Platão, grego; Apuleio, latim; e Bocaccio, toscano. Se a história de Heródoto se reduzisse em verso, seria história nem mais nem menos, pois não tem parte de imitação, a que se deve a diferença. Já Homero, porque imita, é poeta; Empédocles não, porque não imita quando escreve em verso as coisas da filosofia natural. O mesmo se pode dizer de Lucrécio e de Lucano, ainda que se dá por diverso respeito.

A poesia escreve uma só ação de um só homem, as demais por acidente; a história muitas ações e de muitos homens, ainda que trate de uma ação somente - como a conspiração de Catilina ${ }^{1}$ e a Guerra de Jugurta ${ }^{2}$ que historiou Salústio, e outras semelhantes histórias - seu ofício é tratar de muitas e diversas ações.

O poeta trabalha com o universal, atendendo à simples e pura ideia das coisas (e por isso a preferiu em sua Poética Aristóteles), o historiador com o particular, representando as coisas como elas são, tal qual o pintor que retrata ao natural, referindo às coisas como foram feitas. O poeta representa as coisas como necessariamente haveriam de ser ou como poderiam verossímil ou provavelmente ser. Se observarmos somente a superfície das coisas, o poeta olha o particular também, quando Píndaro, Simónides, Alceo e outros poetas gregos cantam os elogios particulares de vivos pelos seus interesses e de semelhantes: deixo os que seus amores pela maior parte trataram. Também o historiador desta maneira olha o universal, pois todo seu fim é ensinar universalmente a bem viver com os exemplos, com as orações adequadas às pessoas, tempos, coisas e casos: ensina a dizer e fazer, contando a natureza das pessoas, seus elogios, injúrias e outras partes cheias de doutrina civil com mais prudência que dão os preceitos dos filósofos, porque é da história que tiram os preceitos que deram.

O poeta, depois que se propôs a imitação de alguns, a mantêm sempre do começo ao fim. O historiador, como encontra os homens os determina ou varia, mutáveis ou constantes, bons ou maus, segundo os tempos.

A poesia é junta e encadeamento que faz uma de muitas, pela finalidade das ações, como uma senhora que ordena outras ministras e servas por meio de

\footnotetext{
${ }^{1}$ Luis Cabrera de Córdoba faz referencia à conspiração comandada pelo senador Lucio Sergius Catilina contra a República Romana. Desse fato, ficaram conhecidas as Catilinárias, um conjunto de discursos proferidos por Marco Tulio Cícero contra Catilina (N. do T.).

2 Referência à Guerra de Jugurta, que envolveu os cônsules romanos Quinto Cecilio Metelo Numidico e Jugurta. A história desse episódio foi narrada por Salústio, no livro chamado Guerra de Jugurta (N. do T.).
} 
episódios, que da sua natureza e propriedade sempre tem o olhar e respeito à fabula, parte substancial e como a alma do poema. A ordem da história é mais incerta e disjunta porque as ações nela dependem de outras e não tem o olhar a um mesmo fim. Esta segue a ordem das coisas mesmas do princípio ao meio e deste ao fim, como tem sido feitas procedendo.

A poesia começa do meio, algumas vezes deixando coisas para os episódios que toma e traz à memória, como a Ilíada e a Odisseia de Homero, e a Eneida de Virgílio, claramente mostram. O poeta, não tendo limite algum em seu julgamento, como passa pela fantasia, põe em movimento, muda as ações, as aumenta, as diminui, as variam, as enfeitam, as amplifica e como já foi mencionado, narra as coisas como deveriam ser feitas e não como foram. Busca fora matérias verdadeiras, prováveis ou falsas, sem semelhança de verdade, para que saiam mais, pareçam maravilhosas e mais estupendas, para que agradem mais: como são as fábulas e as transformações de Ovídio. O histórico tem seus termos e dentro deles a finalidade da matéria que se dispôs a escrever, não se pode sair disso e nem alterar alguma coisa e, assim, não insere, nem retira, mas narra a verdade do fato, ainda que com ornamento e estilo, como é exigido e não de outra maneira. Introduz pessoas falando de diversas nações e modos de viver, de que são exemplos os gregos e latinos, com suas orações retas. César, porque as usou de maneira tortuosa, disse que escrevia comentários, tão capazes na opinião de Cícero, bem acabados e perfeitos por todas as partes da história, que não falta lugar que a mencione, a não ser às orações para sua amplificação.

204 o poeta adiciona pessoas de fora, como deuses, ninfas, adivinhos, oráculos, dá vozes humanas e fala de coisas inanimadas, faz epopeias que não existem, a não ser por fingimento. Disto carece o histórico, mais regular nas palavras e nas sentenças. A poesia, como no número é mais estreita, nas palavras mais livre, de sorte que não se contenta com vocábulos antigos e usa vocábulos novos e os formam de novo ou os apropria de outra língua, fazendo mais vagos os poemas, mais agradáveis e mais afastados do vulgar.

No dizer do histórico não há outro sentido diferente do que possui as palavras, mas o poeta sim, oculta debaixo do véu de suas ficções e misteriosas fábulas alguma doutrina boa ou heroica virtude.

Em que convém a poesia e a história: são semelhantes no sentido de que cada uma propõe a causa e o que há de escrever. Ambas usam do gênero demonstrativo e deliberativo em que algumas vezes inclui o judicial, condenando vícios, elogiando as virtudes, e introduzem os parlamentos e consultas. Ambas com suma indústria guardam a prudência e o decoro, ensinam, agradam, movem, ajudam - a história ainda mais. Cabe as duas fazer menção às coisas antigas e às descrições, com vários acontecimentos súbitos, muitos casos variados e incertos, cheios de áurea de temor, áurea de esperança, áurea de alegria, áurea de dor. A história descobre a ira de Deus: conta os prodigiosos votos e sacrifícios com que apazigua. A poesia com estas coisas e respostas dos oráculos, acompanha os conselhos dos deuses, suas discórdias e feitos. Ambas são vagas nas digressões, amplificações, na variedade, na escolha das coisas e das palavras; trabalham sua boa disposição 
e decisão. Tem seus números, suas figuras para dizer, embora por diversas razões, para estar enfeitada.

A história tem mais do honesto, grave, exemplar, como mais ilustre e sábia. A poesia, jovem e gentil, alguma vez com estilo e formosura, lasciva, com licença e diferença entre a nobre e a plebeia.

\section{Discurso V: Das boas partes do historiador}

O eficiente da história se chama historiador e assim o chamaram os antigos; em Castilha, coronista, que não significa coisa alguma e chronista, que significa um pouco mais. Crónica deriva-se de chronos, nome grego que significa tempo e será temporalia e temporal o escritor, considerando a nominação de uma das quatro partes que consta o quadrívio da uma história, que são: chrónico, pragmático, tópico e genealógico.

Os antigos provaram com vários silogismos e figuras que o historiador se refere somente ao sábio, sem dizer a quem; ao filósofo pelo moral e o natural, ao dialético por provar com argumentos, ao matemático por tratar da magnitude nas descrições, ao orador por persuadir com a suave e adornada oração, com que sobre a invenção, disposição e elocução, diz prudente e de forma enfeitada, e narra lúcida, clara, provável e esplendidamente sobre a matéria comum, que é dizer das coisas feitas ou que se faz o ofício de historiador. E por isso dizemos que ele contém o saber e o objeto de todos, embora chamado de historiador, é filósofo, matemático, dialético, orador, mostrando sê-lo quando escreve. Representa, segundo se tem dito, o governo da cidade, a constituição das leis, o culto da religião, a virtude, os costumes, os conselhos, os feitos dos homens - que é parte da ética e parte da política -, por ser conforme uma e outra no modo em que a prática é conforme a teoria. Das duas pernas que sustentam o corpo do governo do império, uma é a história e a outra a filosofia, ainda que escreva por seu próprio método conforme as leis e os preceitos que possui, ensinando os Elíseos e o Inferno.

Tanto é necessário saber para fazer uma história regular e muitos não acertam o ponto. Tanta dificuldade parece ter os escritores vulgares, que se contentam em dizer que descobriram a verdade dos sucessos e dos tempos e, embora digam como quer, não advertem palavra de ética e de política. Havendo uma guerra, que de penas a ameaçam no mundo, sem arte e natureza para saber começar, prosseguir e acabar! Não sabem o que dizer, calar, elogiar, julgar, acreditar e nem a ordem como devem pôr as coisas. Enganam-se os que pensam que a historia não tem artifício; tem sua doutrina, leis, confirmadas com prudência pelos claros mestres.

Outros, não sendo cuidadosos com a fidelidade, têm cuidado somente com a elegância artificial, castigada, polida, para que o leem porque foi bem escrita. O resultado (segundo diz Políbio) são histórias de uns e outros, como uma donzela formosa na feição, mas que não tem olhos ou tendo-os formosos, tem buracos de varíola no rosto, ou nos demais locais é defeituosa. A alma da história e a virgindade desta donzela é a pura e limpa notícia das coisas, sem interesses e sem respeitos; mas se é gaga ou cheia de lugares grosseiros e verrugas, ninguém se apaixona por ela. 
São as boas partes de um historiador as de legítima e perfeita história que, se soubessem ou entendessem bem a dificuldade que há para fazê-la, haveria menos atrevidos e imprudentes.

É preciso saber boas letras, aprender as divinas, ser doutor em antiguidade, prático no mundo e que o tenha peregrinado, exercitado em todas as matérias, principalmente de estado, ser inteligente das coisas de guerra, bajular os governantes, ser bem relacionado nos negócios públicos e governos de reinos, províncias e povos, inquiridor dos feitos ocultos, cheio de sentenças e ditos graves, instruído em exemplos, erudito, eloquente, grave, severo, urbano, diligente, medido, estudioso, de grande cabeça, bondade e justiça, homem realmente bom para que não acrescente e nem retire mais do que conforme a razão permite a cada um, preparado para escrever com inteira saúde, gênio tranquilo, e colocado do alto para historiar, que não espere e nem tema, que seja conhecedor do bem e do mal que há nos escritores, com perfeita prudência, tanto no dizer como no calar, que seja moderado em seus afetos, que tenha boa escolha em tudo, alma forte ara dizer a verdade e seu parecer, igualdade em contar as coisas dignas de ser louvadas ou repreendidas.

Dizer-se homem realmente bom, porque ainda os gentis o querem assim, parecendo-Ihes que se a oração é a imagem da alma, do mais puro e cândido, será mais pura e cândida a oração. Xenofonte, de Halicarnasso, é tido por justo, tratável, constante, religioso; Filisto por bajulador, humilde; Salústio por vicioso; Heródoto por suave, agradável; Tucídides, por austero, rígido, afeito de ânimo,

206 segundo o engenho, estado, estudo e idade; sendo a gravidade e verdade da história e do escritor a integridade de sua inculpável vida. Claro está que um virtuoso deverá escrever somente o que estiver conforme a razão e a verdade. Escrevem histórias o papa Santo Gregório, Santo Gerônimo, Santo Isidoro - que devemos dar crédito. 